\title{
A record of ethnographic objects procured for the Crystal Palace exhibition in Sydenham
}

\author{
Silje Opdahl Mathisen
}

\begin{abstract}
This article investigates the events surrounding the discovery of a double set of Sámi artefacts collected in Norway in the 1850s. While the collecting had received government funding and was initiated by a Norwegian scholar, the commission for it came from London. One set of artefacts was to be exhibited at Crystal Palace in Sydenham, a commercial venue reaching a tremendously large audience. The other set became part of the Ethnographic Museum in Oslo, a much smaller scientific institution established in 1857. By turning the spotlight on the historical context and agencies of these two sets of artefacts, this chapter examines the notions of early ethnographic practices. ${ }^{1}$
\end{abstract}

Keywords: Sámi collection, ethnographic museums, Crystal Palace in Sydenham, Ludvig Kr. Daa, Dr. Robert Gordon Latham, Kautokeino uprising.

In the archive at the Museum of Cultural History in Oslo, one of the first entries in an old protocol containing various correspondence is a handwritten record dated from 1853 to 1854 entitled: "A record of ethnographic objects procured for the Crystal Palace in Sydenham". Over three pages, numerous Sámi objects are listed, starting with "a complete plaster cast of three Lappish convicts residing at the Christiana Tugthuus (prison)".3

This is a record of the collecting of a double set of Sámi artefacts that had government funding and was initiated by the Norwegian scholar, politician and journalist Ludvig Kr. Daa on the request of the British philologist and ethnologist Robert Gordon Latham. One set was sent to London to be exhibited at Crystal Palace in Sydenham. The other set eventually became part of the collection of the Ethnographic Museum at the Kongelige Frederiks Universitet in Christiania (now Oslo). ${ }^{4}$ The Ethnographic Museum opened in 1857.

This record refers to forms of collecting, studying and exhibiting indigenous people at a time which marked a turning point in the way different global ethnic groups were perceived in relation to each other, and which saw the development of the notion of "race". At the same time, academic disciplines like 


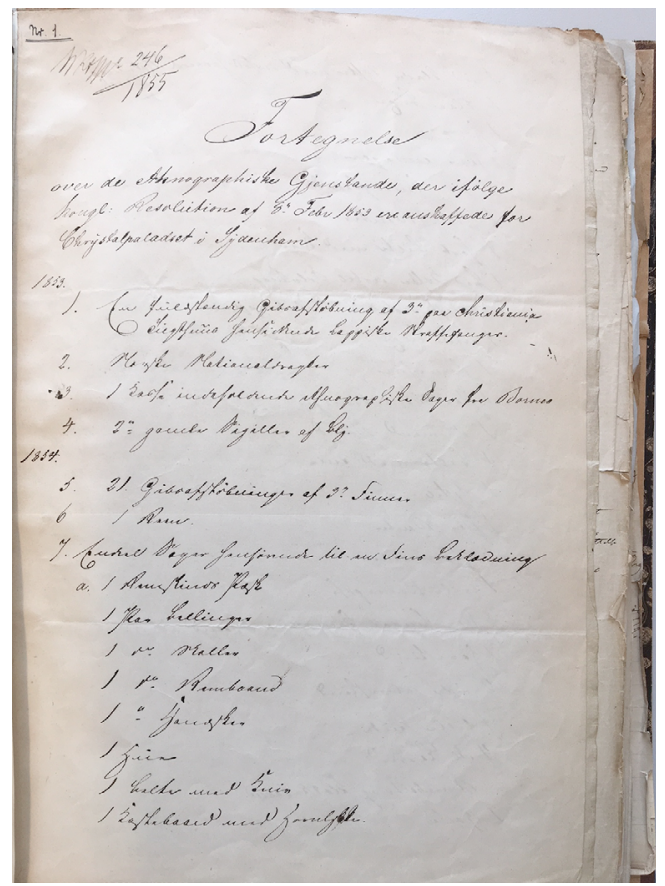

Fig. 1. Page one of the Record of Ethnographic Objects procured for the Crystal Palace exhibition in Sydenham. Photo by the author.

archaeology and anthropology were emerging and this all coincided with the start of what has been called "the exhibitionary complex", an emerging network of world's fairs and museums that provided the cultural underpinning for the development of the modern nation-state (Bennet 1995; Rydell 2011:136).

The record draws on two separate events: the exhibition at Crystal Palace in metropolitan London, and the founding of an ethnographic university museum in the small Norwegian capital of Oslo. In the following, I will examine the milieus in which the Sámi artefacts were collected and exhibited - in Oslo and in London. What notions of race and ethnicity prevailed at that time? How was this institutionalised in universities and museums? processes connected to the collection and exhibition of the objects, focusing on some of the main players and institutions involved in the process. This may contribute to an understanding of how the Sámi were perceived in relation to other indigenous peoples and in relation to the majority population in Norway in the mid-1850s. Moreover, an examination of the processes concerning the record can contribute to a better understanding of the earliest institutionalised research on Sámi culture at the University of Oslo.

\section{A RECORD OF ETHNOGRAPHIC OBJECTS}

The record is two and a half pages long and handwritten in the gothic style. It has eight entry numbers with several sub-numbers. The first four entry numbers are dated 1853 and the rest are from 1854. Of the four entries from 1853, only the first is related to Sámi culture: plaster casts of three Sámi convicts at Christiania Prison in Oslo are described. The other record entries from 1853 are old lead seals, various imported ethnographic objects from Borneo and national costumes from Norway. ${ }^{6}$

All the entries on the list dated 1854 refer to Sámi objects. Entry number 5, which is the first entry from 1854, also describes plaster casts, this time twenty-one plaster casts of three Sámi. According to a later director of the Ethnographic Museum, Yngvar Nielsen, these plaster casts were duplicates of those made in 1853 (Nielsen 1907:8). Entry number six is a reindeer. It does not specify whether this was a real reindeer or a mannequin, or whether it was the hide or a stuffed and mounted reindeer. Entry number seven, which mainly describes items belonging to the Sámi dress/costume, is 
by far the longest entry; it alone spans almost two handwritten pages and points to the importance of the Sámi costume in exhibitions of Sámi culture. Entry number seven is a long list of various items "belonging to the Sámi dress". Among these are a fur coat (beaska) and two tunics $\left(\right.$ gáktis $\left.^{7}\right)$, one pair of fur trousers or longs socks (biddu or gálssot) and three pairs of boots (gápmagat), of which one pair is for a woman and one pair probably for a child as they are described as small. Furthermore, there are also three belts, all with knives (probably niibeboagán), two headdresses plus one headdress for a woman, ${ }^{8}$ and two pairs of trousers (buvssat). At least three whole costumes can be reconstructed based on these objects, of which one was for a woman and one for a child. Under the same entry number there are also some objects that we might not immediately think of as belonging to Sámi dress: a sledge (geres), and two entries: "Reenbelte og klokkebånd” and “Tøm", that I interpret as being part of a reindeer harness (leanyggat), plus other objects like a milk bowl (náhppi) and a small loom (probably a njuikun). Apart from the reindeer and the objects connected to reindeer husbandry, the collection seems to emphasise the human body and how it was dressed. The whole record starts, as mentioned, with the plaster casts of heads, and ends with entry number eight: "head hair from 4 Lapper” (Sámi). The physical body, and how it was dressed, was apparently essential in the representation of Sámi culture (Mathisen 2017).

\section{LUdvig Kr DAA AND THE FOUNDING OF AN ETHNOGRAPHIC UNIVERSITY MUSEUM IN OSLO}

The collecting of Sámi objects has a long history and can be traced back to at least the seventeenth century. The practice of exhibiting living "exotic" people has been documented since the fifteenth century (see for example Broberg 1981/1982; Baglo 2006, 2011; Qureshi 2011:2; Mathisen 2014; Nordin \& Ojala 2018:303). The nineteenth century witnessed significant changes in the scale and nature of such human displays, which reached their peak in the wake of the Great Exhibition at Crystal Palace in London's Hyde Park in 1851. After the Great Exhibition, the building was taken down and moved to Sydenham, where it was rebuilt and extended considerably. The objects in the record were collected so they could be exhibited in the Court of Natural History in Crystal Palace. Robert Gordon Latham was in charge of making the exhibition about the people of the world, which he categorised into different ethnological races. According to the British cultural historian Sadiah Qureshi, Latham's exhibition had great impact on the general view on human races (Qureshi 2011b).

The history of the record starts with a request from Latham to his Norwegian friend Ludvig Kr. Daa. Latham asked Daa if he could assist in collecting Sámi ethnographic objects to be displayed in a "Lappish" section in the People's Palace. In return, Latham would provide other ethnographic objects. Latham had spent time in Norway in the 1830s, where he befriended the writer Henrik Wergeland and Ludvig Kr. Daa. Daa (1809-1877) was a Norwegian historian, ethnologist, politician and journalist. He grew up in northern and western Norway, where his father worked as a priest. A man of many talents, Daa was also a controversial figure who was said to have a difficult personality (Gran 1911). He studied philology in Oslo and was a close friend of Wergeland, but they later had a public falling out. When Daa applied for the vacant position as lecturer in history at the University of Oslo, 
he was passed over in favour of Peter Andreas Munch, who did not have formal training in history but was a less controversial figure. Daa held several positions as a politician, journalist, head of archives and teacher of history until he was appointed director of the Ethnographic Museum in 1862 and was made professor in 1866. He was the director of the museum until 1877. According to Yngvar Nielsen, Daa was the first director who actually cared about the collection (Nielsen 1907:24). ${ }^{9}$ This is evident from the report he wrote to the Collegium Academicum in 1862, complaining about the sorry state of the collection (Ludvig Kr. Daas innberetning til det akademiske Kollegium 16. october 1862). Aside from trying to save the collection from relentless attacks from moths, Daa made a systematic catalogue based on a geographic principle (Nielsen 1907:32). It is worth mentioning that Daa also erected an early example of an outdoor museum when he, in 1873, built a Sea-Sámi dwelling in a corner of the university garden. The houses proved to be difficult to maintain and had to be removed in 1880 (Nielsen 1907:46; see Baglo, this issue).

Daa wrote several history books and was especially interested in comparative questions about peoplesand nations based on ethnological material. In the essay "Om Nationaliterenes udvikling" (On the development of nations) (1869) he was one of the first in Norway to draw on Darwin's theories. In this essay, Daa rejected the "immigration theory" advocated by the Norwegian historians Rudolf Keyser and Peter Andreas Munch. Munch and Keyser were the foremost historians in Norway from the 1830s to the 1850 s, promoting a Norwegian national identity. Daa claimed that Keyser and Munch's theory, which explained change as a result of catastrophes or revolutions, was outdated. He took a more evolutionary view and based his research on the British ethnologist
James Cowles Prichard's (1786-1848) work Researches into the Physical History of Mankind (1813) where change was explained not as a rupture between different races of man, but rather as a result of many small changes over a long period of time (Kyllingstad 2004:46).

In response to Latham's request for Sámi objects, Daa formed a committee consisting of himself, Professor Christian Boeck, curator, and later, Professor Laurits Esmark, Professor Halvor Heyerdahl Rasch and research fellow, later Professor, Jens Andreas Friis. ${ }^{10}$ The committee suggested collecting a double set of artefacts. One set would be sent to Latham in London, and the other would be kept at the University of Oslo and become part of an ethnographic collection. The committee sent an application to the Collegium Academicum at the university requesting a sum of 150-200 Speciedaler ${ }^{11}$ for this purpose. The application went all the way to the Norwegian Parliament (Stortinget), which accepted the application in a Royal Decree dated February 8, 1853. The Collegium asked the abovementioned Professor Munch to make the necessary arrangements for storing the ethnographic objects, presumably in the new university buildings that were being erected in the centre of Oslo.

The completion of the university buildings was delayed, and in 1855, the Collegium asked for a status report from Daa's committee. Daa, Esmark and Rasch reported that the money had been spent on plaster casts of the heads of three Sámi men, made by the brothers Giacinto and Pietro Guidotti for the sum of 36 Speciedaler. Friis had bought costumes and other objects including a "pulk" (sledge) with a harness for 94 Speciedaler, and he also bought Sámi hair for four Speciedaler. ${ }^{12}$ Half of the collected objects had been sent to Latham in London. In return, the university had received 
12 ethnographic objects, mainly from Borneo and Sumatra. Regarding the plaster casts, the committee reported that they had ordered one set for the university collection, and seven sets to be use for exchanges with other museums (Nielsen 1907:8).

According to Yngvar Nielsen, the request from Latham was the catalyst for the founding of the Ethnographic Museum in Oslo (Nielsen 1907:1ff; see also Gjessing et al. 1957). There was already a small collection of ethnographica at the university, but it was stored with the coin collection and the archaeological objects. According to Yngvar Nielsen, the initiative to found an independent ethnographic collection and to open an ethnographic museum came from Latham in London, and from the Ethnographic Museum in Copenhagen, led by the Danish antiquarian Christian Jürgensen Thomsen. The museum in Copenhagen was widely acclaimed to be the best ethnographic collection in the world. When the Ethnographic Museum in Oslo opened to the public in January 1857, it was housed in three small rooms on the top floor of the newly erected university building. When it opened there were only 197 entries in the catalogue. Catalogue entries number 11-58 are called the Latham collection, that is the objects Latham sent in exchange for the Sámi objects (Nielsen 1907:15-16).

\section{EARly Sámi Research at Kongelige FrederIKS UNIVERSITET}

When the Sámi objects in the record were collected, Sámi and Finnish language courses were already being taught at the University of Oslo, although only periodically and intended especially for clergymen who were going to work in Finnmark. When Daa's cousin Jens Andreas Friis was appointed professor of the Sámi and Finnish languages in 1866, this became a permanent position.

Nils Joachim Vibe Stockfleth (1787-1866) was a Norwegian priest and missionary among the Sámi. He also acted as Friis' mentor at the University of Oslo. Stockfleth is credited for being the "second founder" of the NorthSámi written language, after Knut Leem (1697-1774), and for having re-introduced the scholarly study of the Sámi language (Gran 1911:346; Niemi 2009). According to historian Einar Niemi, the influence from German romanticism and more liberal views on minorities that emerged after the Napoleonic wars led to a "rediscovery" of the Sámi as an ethnic group in the first half of the nineteenth century, and Niemi credits Stockfleth for this (Niemi 2009). Stockfleth's most important work was on Sámi language research, translations of religious texts and religious education among the Sámi.

Stockfleth was convinced that the Sámi had a "holy right" to their own language and nationality, and that it would benefit the society as a whole if the Sámi were allowed to develop their own language and culture. This pluralistic view was strongly criticised during the 1840s, and was on the verge of disappearing altogether around 1850, due in part to a growing Norwegian national sentiment. On Stockfleth's last journey to Finnmark in 1851-1852 he played an unfortunate role in the controversies leading up to the Kautokeino uprising. He was asked by bishop Juell in Tromsø to travel to Kautokeino in the hope that he could "smooth the waters" among the supporters of the Laestadian faith. Unfortunately, Stockfleth acted in anger, and beat some of the people involved with his walking stick and his behaviour probably contributed to the uprising escalating out of control (Niemi 2009).

Jens Andreas Friis and Ludvig Kr. Daa 
were cousins, and as mentioned, Friis was a member of the committee that collected the Sámi objects on Latham's request. Friis (18211896) was a writer and one of the foremost Sámi linguists. He studied theology and the Sámi and Finnish languages under Stockfleth's tuition. From 1847 to 1849 he was a university fellow in the Sámi and Finnish languages at the University of Oslo, before travelling to Kajaani in Finland in 1849 to study under Elias Lönnrot. Lönnrot was a Finnish physician, philologist and collector of traditional oral poetry. On this journey, Friis spent eight months in Finnmark (Gran 1911:346). From 1851 to 1863 , Friis was hired to take over for Stockfleth in teaching the Sámi languages at the University of Oslo, while also working as a translator. He was made professor in the Sámi and Finnish languages in 1866. Friis made numerous journeys to the north of Norway. $\mathrm{He}$ was not only a man of science, but also a hunter, fisher and mountaineer, and he was fascinated by the ways of life of the reindeer-herding Sámi. For many he is best known for his novel Lajla - which could be referred to as the Sámi version of Uncle Tom's Cabin. He published widely, producing scientific and literary works and writing in newspapers. In the latter, he raised awareness of the discrimination against the Sámi (Lindkjølen 1983). Friis was also interested in Sámi cultural history, mythology and ethnography. In 1861 he published an ethnographic map of Finnmark, a groundbreaking work that offered insight into both

Fig. 2. The "Bushmen" (Khoisan) display from the Crystal Palace exhibition. Reproduced by permission of the Pitt Rivers Museum, University of Oxford, catalogue no. PRM 1998.211.9.

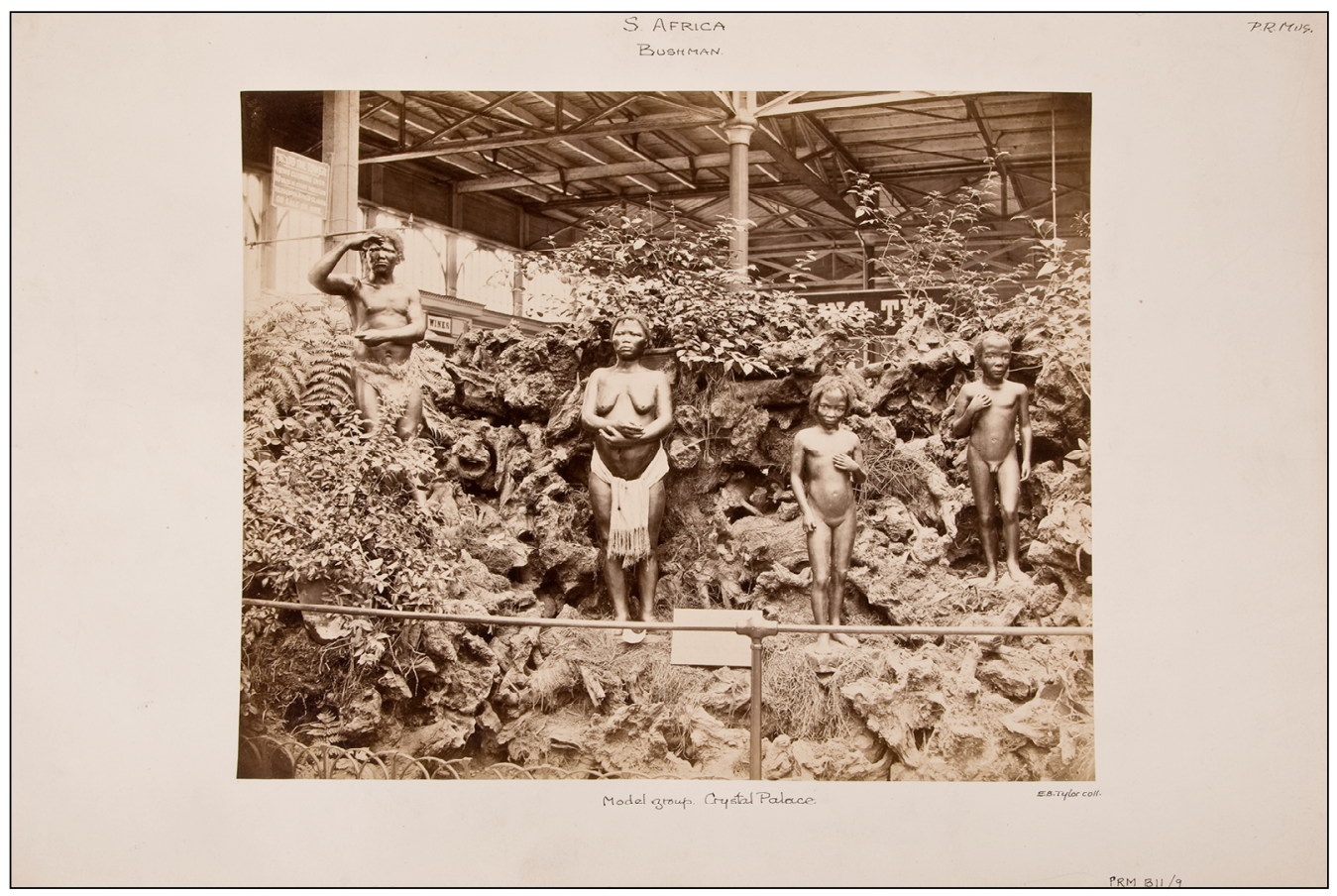


14 ethnicity and language, as well as the Sámi ways of life and living conditions. ${ }^{13}$ In 1867, Friis, Daa and the Sámi Lars Jacobsen Hætta travelled together to Finnmark, Kolahalvøya and Finland (Gran 1911:346-347; Lindkjølen 1983).

\section{ROBERT GORDON LATHAM AND THE Courts of Natural History in Crystal Palace}

Hoping to capitalise on the success of the Great Exhibition ${ }^{14}$ in Hyde Park in 1851, a private company, the Crystal Palace Company, relocated the building to Sydenham where it was extended before opening to the public in 1854. Crystal Palace, also called the People's Palace, was not an international trade fair like its predecessor in Hyde Park, but rather a pantheon of national edification and entertainment. As the entrance fee was reasonable, it attracted a large number of visitors, with more than 1,3 million visitors the first year (Piggot 2004:164).

The building was surrounded by a vast park with fountains and a lake with an island inhabited by full-scale models of antediluvian monsters and extinct reptiles. With a walk starting from the antediluvian monsters, through the Courts of Natural History and continuing through to Art and Technology, the exhibitions at Crystal Palace, seen as a whole, emphasised the potential for improvement and had an overarching theme of progress.

Guidebooks suggested that visitors should start their tour from the South Wing entrance. In doing so, they would enter the Courts of Natural History. This exhibition, the result of a collaboration between Latham and Edward Forbes, a professor of botany, was a major innovation: a small-scale museum of man in his natural habitat. Growing plants, animals stuffed and mounted, and models of foreign peoples were arranged in scenes against a backdrop of painted images (Qureshi 2011:195). The whole court was arranged like a map, divided between the Old World in the southeast and the New World in the southwest. According to the British cultural historian Sadiah Qureshi, the human models were the primary attraction in the Courts of Natural History. They were lifelike, painted plaster casts arranged in visual narratives deemed by Latham as representative of their respective ethnicities (Qureshi 2011:196). Many casts were made from individuals who were either exhibited or living in London at that time (Qureshi 2011:209). If the Sámi objects were exhibited, they would probably be arranged in a family group together with a stuffed reindeer pulling a sledge, a common trope in representations of the Sámi (see Mathisen 2014; 2017). The Sámi objects that the committee led by Daa collected would be sufficient to make such a representation.

In the guidebook accompanying the exhibition, 79 of 92 pages are written by Latham and dedicated to ethnology. Part II, from pages 80 to 92 , is about zoology and botany and written by Forbes (Latham \& Forbes 1854). Latham uses the first two pages to describe what ethnology is: the study of human variety (Latham \& Forbes 1854:5). According to Qureshi, the guidebook's accessibility in both style and cost (only six pence) makes it likely that this was one of the most widely used ethnological works of the 1850s (Qureshi 2011:198).

Robert Gordon Latham (1812-1888) was an English ethnologist and philologist. During his philology studies, he spent a year abroad, first in Germany, then in Denmark and finally in Norway. He published a two-volume book about Norway and the Norwegians which he dedicated to his friends Wergeland and Daa 
(Latham 1840). In 1839 Latham was elected Professor of English Language and Literature at University College, London. He then decided to enter the medical profession and obtained the degree of M.D. at the University of London. He became a lecturer on forensic medicine and was elected assistant-physician at Middelsex Hospital. His interests henceforth developed towards ethnology and philology and he abandoned medicine in 1849. In 1852 he became director of the ethnological department at Crystal Palace, Sydenham.

Latham was not just an "armchair ethnologist” (see Stocking 1987:79, 108-109; SeraShriar 2013:5-12). He was already a professor in English when he then retrained as a physician and built a medical carrier. In other words, he was thoroughly schooled in both the linguistic and biological/anatomical approaches to the study of man. Latham rose to prominence after the death of Prichard. He was elected to the Royal Society in 1848 and published The Natural Histories of the Varieties of Man in 1850, the same year as Robert Knox's Races of Man (Sera-Shriar 2013:82-95). He served as the vice-president of the Ethnological Society and was given the curatorship of Crystal Palace's Courts of natural history. All this suggests that Latham had a prominent position at the time, and Qureshi suggests that his work was not seen as outdated in the mid-1850s, as has been suggested by historians who reads Knox's publication as indicative of a new area of scientific racism (see Qureshi 2011;216-217, note 121). By reading Latham's work in the Courts of Natural History at Crystal Palace, Qureshi sees it as neither a humanistic, textbased approach in line with Prichard, nor as having adopted anatomy and physiology as his primary rationale for defining human variation (as Robert Knox and James Hunt). She sees Latham's work as a heterogeneous mix of many elements, including natural history, philology, anatomy and physiology. Latham's work in the Courts of Natural History, and his prominent position in the Ethnological Society, suggest that both ethnologists and the bourgeoisie looked to Latham, not Knox, for their ethnological education. This suggests that the mid-nineteenth century saw a substantial proliferation, not a homogenization of approaches to the scholarly study of human variation (Qureshi 2011:217-218).

The mid-nineteenth century marked a turning point in the view on the different peoples of the world. Until then, this view had two major influences: Jean-Jacques Rousseau's romantic view of the noble savage as someone who was more "natural" or closer to nature than modern men and not corrupted by modern life. The other major influence was the importance of the Bible as a historical document. It was a common belief that it was possible to date the age of the earth, and that all men were descendants of Adam and Eve, and in principle equal (monogeneses see Stocking 1987:25). By the late eighteenth century, scholars developed a model of social development in which civilizations naturally passed through distinctive stages characterised by their mode of subsistence: hunting, pasturage, agriculture and commerce (Stocking 1987; Baglo 2011:172-174; Qureshi 2011:189). As a result, non-European civilizations could be perceived as less developed. Among others, Qureshi points to the elasticity of this model on an individual level. If an African learned to speak English, converted to Christianity and dressed in European clothes, he could be classified as a European. This elasticity, Qureshi argues, is often overlooked when biological or colour-based notions of ethnic difference are anachronistically adopted for earlier periods (Qureshi 2011:189, see also note 324). 
British debates between the 1830s and 1860 s were at a significant crossroads for the re-making of the natural history of "race" (Qureshi 2011:187; Sera-Shriar 2013). Between the mid-1840s and early 1870s, scholarly studies of human variety were institutionalised with the emergence of learned societies. The institutional wrangling between these societies ultimately led to their amalgamation as the new Anthropological Institute of Great Britain and Ireland in 1871. According to Qureshi, this has traditionally been seen as taking place during, and contributing to, the re-conception of "race" from being an elastic category, to the emergence of "scientific racism" based on unchangeable, inherited traits based on physiological, anatomical or biological differences. These shifts are again coupled with the transformation of "armchair" ethnology into modern anthropology, that is, an assumed shift from humanistic textual and philological approaches to scientific investigations rooted in biological science and, ultimately, fieldwork (Qureshi 2011:214-215; Sera-Shriar 2013). James Cowles Prichard, Robert Knox and James Hunt are theorists associated with this shift. Knox and Hunt's works are frequently cited as typical of a new tide of Victorian racism and aggressive imperialism. But these views were regarded as highly controversial by many of their contemporaries (Qureshi 2011:215-216).

Latham contributed to the discussions with the exhibition in the Courts of Natural History, and the guidebook accompanying it, by stressing human unity. He arranged the exhibition according to the taxonomic principles of three varieties of man: European (omitted from the exhibition), Mongolian and Negro, and the developmental stages hunting/ gathering, agriculture and commerce (Qureshi 2011:201). As Daa, Latham was a follower of
Prichard, and like Prichard, he held ethnology to be part of historic philology that traced the origins of races through the genealogical relationship between languages. In the Courts of Natural History, Latham used the three-race theory of Georges Cuvier, but preferred to avoid the term "race", using instead "varieties of man" (Latham \& Forbes 1854). Latham was praised for making an innovative exhibition and for creating a promising basis for future research (Qureshi 2011:209). At that time, there were no ethnological museum in London, and after the exhibition was destroyed by fire in 1866 , it was not until the Pitt Rivers Museum in Oxford opened in 1887 that the public could see an ethnological collection again. According to the British historian Efram Sera-Shriar, the Courts of Natural History can also be seen as a type of ethnographic training ground where the exhibition and the accompanying guidebook informed readers and visitors how to observe and interpret the different human varieties on display (Sera-Shriar 2013:95).

\section{THE FATE OF THE OBJECTS IN THE RECORD}

In the following, I will look at how the objects listed in the record could have been exhibited. As already indicated, the objects were collected in two sets: one set was to be exhibited in the Courts of Natural History at Crystal Palace, and the other set was to be exhibited at the Ethnographic Museum in Oslo. Collections of strange objects from faraway places had existed for hundreds of years, but new to the nineteenth century was that the collections were open to the public and financially supported by the government (Bouquet 2012:65). The history of exhibiting foreign peoples has of course a much longer history. Scholars have pointed to a connection 
between earlier shows and the establishment of ethnographic museums: museums exhibited foreign peoples in much the same way as they were exhibited in the shows, but the museum did not have live people, able to talk and act, but rather "people" as representations, in the form of still plaster casts (Qureshi 2011; Baglo 2011). In the late nineteenth century, anthropologists were often responsible for curating displays of foreign people into sequences representing racialist evolutionary hierarchies (Qureshi 2011:186). It can be argued that they used the fairs not only to show or publicly validate anthropology, but also to actually create and establish anthropological knowledge. Museum exhibitions are not only a pure dissemination of meaning. The making of an exhibition is also a process that creates meaning. By collecting, classifying and juxtaposing objects, museums affect and influence people's perceptions of them (see Ruud 2018). This is particularly the case when university museums collect and exhibit objects due to their presumed authority in presenting "the truth".

How then were the Sámi objects that Daa and his committee made such an effort to collect, exhibited? At Crystal Palace, the question is rather whether they were exhibited at all. In Latham and Forbes' handbook for the exhibition, there is no mention of the Sámi. Including the "Esquimo" (Greenlanders) exhibited in the arctic region, the handbook lists 12 groups of peoples, with subgroups. None of these are Sámi (Latham \& Forbes 1854). Another contemporary guidebook for the Courts of Natural History is Samuel Philip's Guide to the Crystal Palace and its Park (1854). There is no mention of Sámi objects or of a representation of Sámi people here either. When entering the Ethnological and Natural History department, the first section a visitor would come upon was the Arctic regions.
According to Philips, two polar bears and a group of "Esquimaux" represented the arctic regions (Philips 1854:104). Is it possible that the Sámi objects and plaster casts were not shown?

In the handbook, Latham writes that the Greenlanders are the family of peoples that occupy Greenland, the coast of Labrador, the northern coast of North America and the shores of the Arctic Sea, both east and west. They extend to Russian America, to the other side of the Behring Straits and to the Aleutian Islands. Latham also writes that the Esquimo is the only family common to the Old and the New world (Latham \& Forbes 1854:77-78). In the handbook, Latham thanks professor Thomsen from the ethnological museum in Copenhagen for providing the Greenlandic material, but there is no mention of Daa or of the collaboration with the University of Oslo.

Based on the examination of contemporary handbooks written by Latham and Forbes, and Philipps, it seems that the Sámi objects were never a part of the exhibition at Crystal Palace. One can only speculate why. Did Latham confuse the Greenlanders and the Sámi, as might be interpreted out of the description of the Greenlanders in the handbook? However, seeing as Latham had stayed in Norway and that he wrote about the Sámi in his book about Norway I find this hard to believe (Latham 1840). Another argument against this theory is that Latham made two separate requests: one to Daa in Oslo asking for Sámi material, and one to Thomsen in Copenhagen asking for Greenlandic material.

Latham was criticised for not making the peoples of Britain and Europe a part of the exhibition in the Courts of Natural History (Qureshi 2011:201). He writes in the handbook that this omission was because he assumed that the character of most of the European 
populations was sufficiently understood (Latham \& Forbes 1854:5-6). Can this explain why the Sámi objects were not exhibited? If so, Latham must have classified the Sámi as European, not Mongolian. Perhaps they were hard to place as one or the other? Or could it simply be due to practical reasons, that there was not enough exhibition space, or that the Sámi objects arrived too late? Another aspect to speculate on is the fate of the Sami objects that were sent to London. What happened to them? If they had been exhibited in the Courts of Natural History, as was the plan, they would probably have been destroyed by fire in 1866 . Since it seems that the Sámi objects were most probably not exhibited, there is a chance that some of the objects might have survived until today.

\section{DAA'S INVENTORY}

Unfortunately, apart from the three plaster portrait busts, most of the objects listed in the records have probably been destroyed or lost. I have not been able to trace any of the original objects in the records in any of today's museum collections, neither at the Ethnographic Museum nor at the Norwegian Museum of Cultural History (Norsk folkemuseum). ${ }^{15}$

When Daa took over as a director of the Ethnographic Museum in Oslo, the collection was in such a sorry state that he ordered a full inventory. In a letter to the Collegium Academicum dated October 16, 1862, Daa mentions the fate of some of the objects listed in the record. The rooms where the ethnographic collection had initially been stored and exhibited were not ideal: very hot in the summer and freezing in the winter. As a result, moths caused severe damage to the collection. Daa refers to his predecessor, Professor Monrad, who told him that all the Lappish fur had already been destroyed and had to be removed. The same was true for some of the Lappish garments. Daa also pointed out that the 21 plaster busts that he had helped to collect in the 1850s (number 5 in the records) were missing - they could not be found, neither in the catalogue nor in the collection (Daa 1862).

In a book celebrating the fiftieth anniversary of the Ethnographic Museum, the director, Yngvar Nielsen, lamented a lost opportunity: The Ethnographic Museum in Oslo could have been almost as good as the one in Copenhagen! Important connections were established with Thomsen in Copenhagen and Latham in London. There were great opportunities for collecting, as Norwegian shipping greatly expanded in this period. But alas, Nielsen complains, due to very limited funding and a director - Peter Andreas Munch - who already had too much to do and, according to Nielsen, was "not a museum man", the Ethnographic Museum was not a priority.

Today, little is known of what the exhibitions looked like at the time. The mission and ideal of the Ethnographic exhibition is stated in the annual report to the Collegium Academium in 1857. The ideal was that enough of the nations' tools, weapons, clothing, objects of art and other artefacts would be exhibited so the visitors would have enough data to make a clear conception of each nation's higher or lower development (Nielsen 1907:13-14). Daa was critical of the exhibition when he took over as director. He describes an exhibition that was not ordered geographically and led one to see it more as a Wunderkammer (Ludvig Kr. Daas innberetning til det akademiske Kollegium, 16 October 1862). In contrast, Latham's exhibition was ordered geographically and according to the taxonomic principles of three varieties of man. In 1902, the conditions for storing 
and exhibiting the ethnographic collection improved as it was moved to the newly built Museum of History (Historisk museum).

\section{SÁMI PRISONERS AS OBJECTS OF STUDY - THE ORIGINS OF SÁMI RESEARCH AT THE UNIVERSITY OF OSLO}

I have referred above to the entries in the record as "objects", but there is a degree of ambiguity about some of the items when it comes to whether or not they are objects or actors, namely the three plaster life-mask casts. The names of the people portrayed in plaster are not mentioned in the record. In his book on the history of the Ethnographic Museum commemorating its fiftieth anniversary, Yngvar Nielsen describes them as: portrait heads of Mathis Hætta ${ }^{16}$ "of mixed race, the father a Kven and the mother a Lap from Kautokeino"; Peder Rik "of unmixed Lappish race from Polmak, East-Finnmark"; and Nils Karasjok "of unmixed Lappish race from Karasjok, except that his grandmother was Swedish" (Nielsen 1907:8, my translation).

Who were they? According to the records, they were inmates at Christiania Prison. This puzzled me a bit, as one of them, Mathis Hætta, is a well-known figure from the events leading up to the Kautokeino uprising, and earlier I supposed that he was an inmate at Akershus Prison, another prison in Oslo where the Sámi prisoners from the Kautokeino uprising served their sentences. ${ }^{17}$ At the State Archives, I examined the prison records from Christiania Prison for this period and there they were: Mathis Hætta, Nils Karasjok and Peder Rig, as well as a fourth Sámi prisoner: Rasmus Spein (Fangeprotokoll Kristiania Tukthus. Fanger (FKT). 1850-1857). Both Hætta and Spein were so called Laestadians, religious followers of the Swedish priest Lars Levi Laestadius and

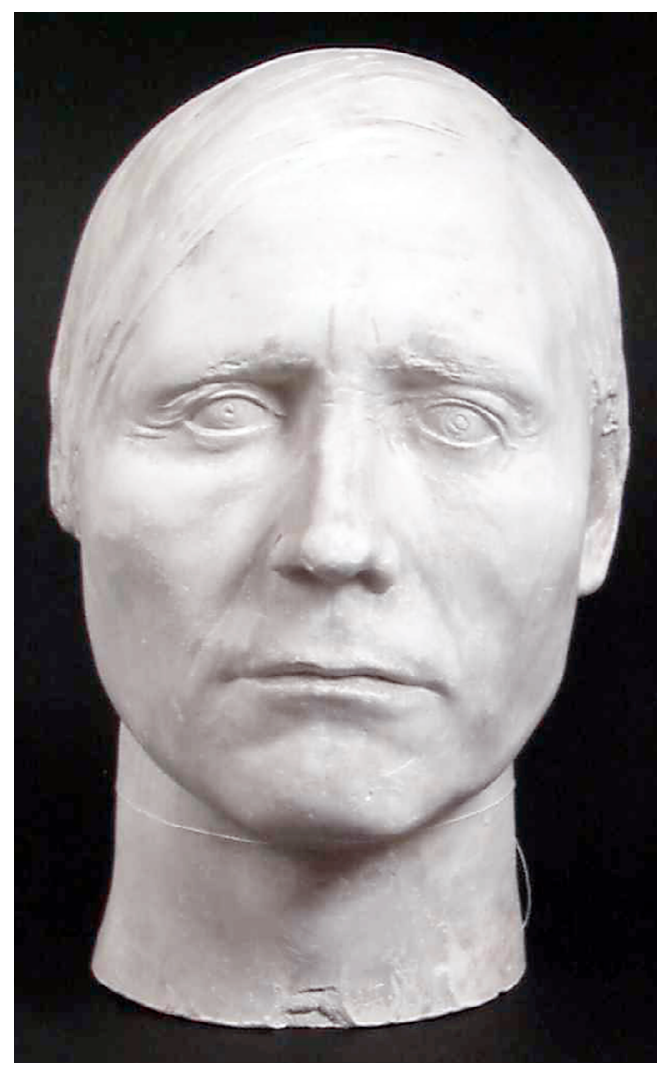

Fig. 3. Portrait head of Nils Karasjok, plaster life-mask cast. Reproduced by permission of the Norwegian Museum of Cultural History (Norsk folkemuseum), catalogue nr. NFSA.3563.

his pietist revival movement. They were among the 22 Sámi who were convicted of disturbing a public sermon in the mainly Sámi municipality of Kautokeino in the interior of Finnmark in northern Norway. Their severe punishment and high fines added to the controversy leading up to the Kautokeino uprising in November 1852, where the local Sámi followers of Laestadius attacked representatives of the authorities and killed the local law enforcer and a local merchant (see Zorgdrager 1998). 
Mathis Hætta and Rasmus Spein were transferred from the prison in Trondheim to Christiania, where they arrived on August 11, 1852. According to the Dutch anthropologist Nellejet Zorgdrager, Bishop Juell arranged for them to serve their time in Oslo, where they could be educated in religious matters in their own language, as this was not possible in Trondheim. Jens Andreas Friis from the University of Oslo was to educate them in their own language (Zorgdrager 1998:289, and note 675). According to the clerical prison records, both Hætta and Spein were defiant and refused to work until they were beaten into submission (FKT. Presten. 1840-1852). Rasmus Spein died in prison on January 28, 1853. Neither the prison records nor the clerical records state the cause of death.

Six months before Mathis Hætta and Rasmus Spein arrived at Christiania Prison, two other Sámi prisoners had been transferred there from the prison in Trondheim. Nils Karasjok and Peder Rig were both from Finnmark and, even though their crimes were not related, they were both convicted of stealing and slaughtering reindeer. Nils Karasjok was sentenced to three years, three months and three days and Peder Rig to two years, two months and five days (FKT. Fanger. 1850-1857). According to the clerical records from the prison, Nils Karasjok could understand a little Norwegian but Peder Rig did not understand Norwegian at all (FKT. Presten. 1840-1852). Why were they sent all the way to Oslo? The clerical records provide the explanation: According to an order from the Ministry of Justice, Peder Rig and Nils Karasjok were moved to Christiania Prison so that Friis could have the opportunity to discuss his work on the Finnish and Northern Sámi languages and his work on a Finnish and Northern Sámi dictionary (FKT. Presten. 1840-1852). ${ }^{18}$ Friis later worked closely with
Lars Jacobsen Hætta on translations from Norwegian to Sámi (Kjølaas 1998; Aarseth 2009; Davy 2018). Hætta was sentenced to death for his participation in the Kautokeino uprising but because of his young age (he was 18 at the time) the sentence was reduced to life imprisonment. In an article about Hætta and his importance as a bible translator, Per Oskar Kjølaas writes that in 1851 Friis applied to the Ministry of Justice to have Sámi prisoners sent from Trondheim to Oslo so they could assist in his studies of the Sámi and Finnish languages. According to Kjølaas, this did not happen until 1856, when seven Sámi prisoners from the Kautokeino uprising were sent to Oslo and Akershus Prison, among them Lars Jacobsen Hætta (Kjølaas 1998:713-714). However, as the prison records from Christiania Prison show, Friis' first application was successful.

When Daa formed his committee so he could collect Sámi objects to be sent to Crystal Palace in London, a scholarly interest in Sámi languages and culture was about to be established at the University of Oslo. This interest had its roots in missionary work and the importance of translating the Bible and religious texts into Sámi. Even though Friis and Lars Jacobsen Hætta also collaborated for many years after Hætta was pardoned, it cannot be underestimated that this collaboration started on very unequal terms, between Sámi prisoners and scholars from the university. The conditions for the Sámi prisoners must have been very difficult, both at the Christiania and Akershus Prisons. As indicated, the clerical records from Christiania Prison state that Mathis Hætta and Rasmus Spein were beaten, and Spein died only six months after he arrived in Oslo.

In 1863, Friis and Daa applied for the release of four remaining Sámi convicts from the Kautokeino uprising at Akershus Prison 
(there were originally seven prisoners but three had already died in prison). The prison management supported the application and wrote that the Sámi convicts had acted in an exemplary fashion, and also pointed out that they had suffered more than usual. They did not understand the language, and because of their faith, they could not drink beer or eat pork (Kjølaas 1998:721). Daa and Friis wrote that it was especially hard for the Sámi prisoners to serve long sentences in a prison far away from their home and under very different conditions than what they were used to. According to Friis and Daa, this must have been an extra burden and probably contributed to some of the Sámi prisoners becoming ill, where some even died. Clearly, Daa and Friis understood at this time that it added to the burden for a Sámi prisoner to be sent to serve a prison sentence in the south of Norway, which must have seemed like a foreign country. But was this an understanding Friis had, and a calculated risk he took, when he arranged for Nils Karasjok and Peder Riik, and later Mathis Hætta and Rasmus Spein, to be sent South or was this an understanding that Friis reached gradually? The death of Rasmus Spein in Christiania Prison might have contributed to this understanding, but still, Friis later participated in a prolonged debate where he argued for the prisoners from the Kautokeino uprising to be sent south as well.

As mentioned above, Peder Rik, Nils Karasjok and Mathis Hætta were brought to Oslo to provide material for Jens Andreas Friis' study of the Sámi language. The three plaster portrait heads in the record actually represent three important suppliers of linguistic data on the Sámi language. There are strong indications that the Sámi informers did not provide their services voluntarily. They were prisoners, subjected to beatings and lived under harsh conditions. The making of the plaster heads was probably not a voluntary process. Lifemask casting, the process of making a threedimensional copy of a living human body or body part through the use of moulding and casting techniques, can be extremely uncomfortable. As mentioned above, additional copies were made so exchanges could be carried out with other museums and institutions. The three plaster heads are now in the collection at the Norwegian Museum of Cultural History. In the record, they are described as "plaster casts of three Lappish Convicts". Today they are catalogued as "portrait heads", each with their name: Nils Karasjok, Peder Rik and Mathis Hætta.

\section{Notes}

1. I would like to thank Jon Barstad at the Archives of the Museum of Cultural History/ Kulturhistorisk Museum for invaluable help in understanding and transcribing gothic handwriting. I would also like to thank Káren Elle Gaup at the Norwegian Museum of Cultural History/Norsk Folkemuseum, and Liisa-Ravna Finbog and Gro Ween at the University of Oslo for their help in searching for objects, translating and reading and commenting.

2. Fortegnelse Over de ethnografiske Genstande, der ifølge Kongl. Resolution af 8 Febr 1853 ere anskaffede for Chrystalpaladset i Sydenham. Universitætets ethnografiske Musæum. Indkomne Breve 1833-1877 Archive reference 246/1855

3. Until the early twentieth century the Sámi were referred to as "Lapper" by Norwegians, and sometimes as "Fins". The term "Fins" was also used for people with a Kven background. The Kvens are a Finnish minority in Norway. In the record, both terms are used.

4. The University of Oslo is the oldest university in Norway, founded in 1811 as Det Kongelige 
Frederiks Universitet, named after the Danish King Fredrik IV, the last king of the DanishNorwegian union. In 1939 the name was changed to Universitetet i Oslo (the University of Oslo). I refer to it simply as "the university". The name Oslo is the newer name for the city. In the 1850s Oslo was called Christiania, after the DanishNorwegian King Christian IV. I refer to it as Oslo.

5. For a clarification on the term "race", see Kyllingstad 2004: 10-11.

6. According to Yngvar Nielsen (1907), this might be a book: Norske Nationaldragter by Chr. Tønsberg (1852).

7. Gávitt is the correct plural for gákti (plural). I have been advised to use the term gáktis here.

8. Not enough is known about which type of headdress or cap this is to give it a correct Sámi term.

9. Yngvar Nielsen (1843-1916) was director of the Ethnographic Museum in Oslo from 1877 to 1916. Like Daa, he was a historian and a professor of ethnography. He was a very productive writer and is known for his travel guides which promoted tourism in Norway.

10. Jens Andreas Friis (1821-1896). Linguist and writer, known as one of the foremost researchers on Sámi languages and Lappology. See also pages 13-14 in this article.

11. Speciedaler (Spd), the monetary unit used in Norway up until 1875.

12. According to the report from the committee, Friis was the one who acquired the objects. Friis made numerous trips to Finnmark, the first in 1850 (Lindkjølen 1983:10).

13. Ethnic maps like this can also be a valuable tool for the government, see Ivar Bjørklund, "Society, Ethnicity and Knowledge Production. Changing Relations between Norwegians and Sámi 1850 - 2000". Forthcoming in Sámi Research in Transition: Knowledge, Politics and Social Change, edited by Laura Junka-Aikio, Jukka Nyyssönen and Veli-Pekka Lehtola.
14. From May 1 to October 15 1851, The Great Exhibition of the Works of Industry of All Nations, also called The Great Exhibition, was open to the public in a temporary building designed by Joseph Paxton and aptly named Crystal Palace. This was the first of the world fairs that became popular in the last part of the nineteenth and the beginning of the twentieth centuries.

15. The Sámi collection was transferred from the Ethnographic Museum to the Norwegian Museum of Cultural History in the 1950s.

16. Nielsen 1907 writes his name as "Matias Hætta".

17. Zorgdrager writes that Mathis Hætta and Rasmus Spein served time together at the workhouse in Christiania (Zorgdrager 1989:299. See also https://digitaltmuseum.no/011023295796/hodeportretthode from the Norwegian Museum of Cultural History, where the collection of the plaster heads is to be found today, and where the text states that Mathis Hætta served time at the Akershus Prison in Christiania.

18. “- Overflyttet efter Justitsdepartementets Ordre tilligemed No. 124 Peder Olsen Rig til xiania Tugthuus for at constitueret Docent i det lappiske og Qvenske Sprog, Cand. thl. Friis, der kunde have Anledning til Conference med dem under hans Beskjæftigelse med det finske Sprog og Udarbeidelsen af finske Bøger." Fangeprotokoll Kristiania Tukthus. Presten. 1840-1852

\section{REFERENCES}

\section{Archival Sources}

The archives of the Museum of Cultural History, University of Oslo/Arkivet ved Kulturhistorisk museum, Universitetet i Oslo

Universitctets ethnografiske Musæum. Indkomne Breve 1833-1877 Archive reference 246/1855. "Fortegnelse Over de ethnographiske Gjenstande, der ifølge kongl: Resolution af 8 Febr 1853 ere anskaffede for Chrystalpaladset i Sydenham." Ludvig Kr. Daas innberetning til det akademiske 
Kollegium 16 October 1862. KHM, Etnografisk museum

\section{The State Archives / Riksarkivet}

Fangeprotokoll Kristiania Tukthus. Fanger. 1850-1857. Statsarkivet, Oslo SAO/A-10644/Had IV

Fangeprotokoll Kristiania Tukthus. Presten. 1840-1852. Statsarkivet, Oslo SAO/A-10644/K/Ka/L0001

Fangeprotokoll Kristiania Tukthus. Presten. 1845-1852. Statsarkivet, Oslo SAO/A-10644/K/Ka/L0002

Domsprotokoll. Kristiania Tukthus. Fanger. Domsprotokoller. 1850-1861. Statsarkivet, Oslo SAO/A-10644//H/Hd/L0004

\section{Literature}

Aarseth, Bjørn 2009. "Lars Hætta”. In Norsk biografisk leksikon. https://nbl.snl.no/Lars_H\%C3\%A6tta. Accessed 1 May 2019.

Andersson Burnett, Linda 2013. "Selling the Sámi: Nordic stereotypes and participatory media in Georgian Britain”. In Jonas Harvard \& Peter Stadius (eds.). Communicating the North: Media Structures and Images in the Making of the Nordic Region. Farnham: Ashgate, 171-196.

Baglo, Cathrine 2006. "Samer på ville veger? Om 'levende utstillinger', antropologi og vitenskapelige praksiser." Nordisk Museologi, 2006, 1, 3-20.

Baglo, Cathrine 2011. På ville veger? Levende utstillinger av samer i Europa og Amerika. Ph.D. dissertation, Universitetet i Tromsø, Institutt for arkeologi og sosialantropologi.

Bennett, Tony 1995. The Birth of the Museum: History, Theory, Politics. London: Routledge.

Bouquet, Mary 2012. Museums: A Visual Anthropology. London: Berg.

Broberg, Gunnar 1981/1982. "Lappkaravanor på villoväger: antropologien och synen på samerna fram mot sekeskiftet 1900". Lychnos 1981/1982, 27-86.

Davy, Jack 2018. “Lars Hætta’s miniature world: Sámi prison op-art autoethnography." Journal of Material Culture 23.3, 280-294.
Gjessing, Gutorm \& Marie Krekling Johannessen

1957. De Hundre år - Universitetets Etnografiske Museums Historie 1857-1957. Vol. 5. Oslo: Universitetets Etnografiske Museum.

Gran, Gerhard 1911. Det Kongelige Fredriks Universitet 1811-1911. Vol. 1. Kristiania: Aschehoug.

Kjølaas, Per Oskar 1998. "Lars Jacobsen Hætta. Opprører og bibeloversetter”. In Alf Isak Keskitalo. Guovdageainnu Suohkangirji = Kautokeino Sognebok. Guovdageaidnu: Guovdageainnu Suohkan.

Kyllingstad, Jon Røyne 2004. Kortskaller og langskaller. Fysisk antropologi i Norge og striden om det nordiske herremennesket. Oslo: Scandinavian Academic Press/Spartacus Forlag AS.

Latham, Robert Gordon 1840. Norway and the Norwegians. Vol. 1. London: Bentley. Latham, Robert Gordon 1840. Norway and the Norwegians. Vol. 2. London: Bentley.

Latham, Robert Gordon 1850. The Natural History of the Varieties of Man. London: John van Voorst.

Latham, Robert Gordon \& Prof. Edward Forbes 1854. A Hand Book to the Courts of Natural History. Crystal Palace Library. London: Bradbury \& Evans.

Lindkjølen, Hans 2009. “J A Friis”. In Norsk biografisk leksikon. https://nbl.snl.no/J_A_Friis. Accessed 11 April 2019.

Lindkjølen, Hans 1983. J.A. Friis og samene. Trondheim: Forlaget Sámi Varas.

Mathisen, Silje Opdahl 2014. Etnisitetens estetikk: visuelle fortellinger og forhandlinger $i$ sámiske museumsutstillinger. Ph.D. dissertation, Universitetet i Oslo; Det Humanistiske Fakultet.

Mathisen, Silje Opdahl 2017. "Still standing: On the use of dioramas and mannequins in Sámi exhibitions." Nordisk Museologi 1, 58-72.

Nielsen, Yngvar 1907. Universitetets ethnografiske samlinger 1857-1907. En historisk oversikt over deres tilbilvelse, vakst og udvikling. Meddelelser fra det Ethnografiske musoum No.1. Christiania: W. C. Fabritius \& sønner A/S. 
Niemi, Einar 2009. "Nils Stockfleth". In Norsk biografisk leksikon, https://nbl.snl.no/Nils_ Stockfleth. Accessed 10 April 2019.

Nordin, Jonas M. \& Carl-Gösta Ojala 2018.

"Collecting, connecting, constructing: Early modern commodification and globalization of Sámi material culture." Journal of Material Culture 23:1, 58-82.

Perminow, Arne Aleksej, Ann Christine Eek \& Jostein Bergstøl 2004. Kulturhistorier i sentrum: Historisk Museum 100 år. Oslo: Kulturhistorisk Museum.

Philips, Samuel 1854. Guide to the Crystal Palace and its Park, Sydenham. London: Bradbury and Evans. Piggot, Jan. R. 2004. The Palace of the People: The Crystal Palace at Sydenham, 1854-1936. London, Hurst.

Prichard, James Cowles 1813. Researches into the Physical History of Man. London: J. and A. Arch.

Qureshi, Sadiah 2011a. Peoples on Parade: Exhibitions, Empire, and Anthropology in Nineteenth-century Britain. Chicago: University of Chicago.

Qureshi, S. 2011b. "Robert Gordon Latham, displayed people and the natural history of race" in: The Historical Journal 54:1, 143-166.

Ruud, Lise Camilla 2018. “Det museale maskineri. Fremstillinger av 'primitive folkeslag' ved Det Kongelige Frederiks Universitets etnografiske samlinger." Norsk museumstidsskrift 4:2, 72-91.

Rydell, Robert W. 2011. "World fairs and museums." In Sharon Macdonald (ed.). A Companion to Museum Studies. Chichester: John Wiley \& Sons.
Sera-Shriar, Efram 2013. The Making of British Anthropology. London: Pickering \& Chatto.

Stockfleth, Nils C Vibe 1860. Dagbok over mine missionsreiser i Finnmark. https://www.nb.no/items/cad80824242520acfd476f83a555f1de?page $=5 \&$ searchText $=$ Nils $\% 20$ Chr.\%20Vibe\%20Stockfleth. Accessed 10 April 2019.

Stocking, George W. 1987. Victorian Anthropology. New York: Free Press.

Zorgdrager, Nellejet 1998. De rettferdiges strid: Kautokeino 1852. Trondheim: Landslaget for Lokalhistorie: https://www.nb.no/items/URN:NBN:no-nb_digibok_2009122100054. Accessed 10 April 2019.

Silje Opdahl Mathisen, Ph.D., Collection manager s.o.mathisen@khm.uio.no

Museum of Cultural History,

University of Oslo

Box 6762. St. Olavsplass

0130 Oslo, Norway

https://www.khm.uio.no/om/organisasjon/ arkeologisk-seksjon/ansatte/siljeopd/index.html 